\title{
Indihome's New Post Activation Control Application Based On Website With Telegram Features
}

\section{Aplikasi Pengawalan Aktivasi Pasang Baru Indihome Berbasis Website Dengan Fitur Telegram}

\author{
(Mochamad Rifqi Aminudin ${ }^{1}$, Arif Senja Fitrani ${ }^{2}$, Mochamad Alfan Rosid ${ }^{3}$, Sumarno $^{4}$ ) \\ ${ }^{1)}$ Mahasiswa Program Studi Informatika, Universitas Muhammadiyah Sidoarjo, Indonesia \\ ${ }^{2)}$ Dosen Program Studi Informatika, Universitas Muhammadiyah Sidoarjo, Indonesia \\ ${ }^{3)}$ Dosen Program Studi Informatika, Universitas Muhammadiyah Sidoarjo, Indonesia \\ ${ }^{4)}$ Dosen Program Studi Informatika, Universitas Muhammadiyah Sidoarjo, Indonesia \\ [rifqiamin97@@gmail.com²,asfjim@umsida.ac.id²,alfanrosid@umsida.ac.id ${ }^{3}$, sumarno@umsida.ac.id ${ }^{4}$ ] \\ ${ }^{1}$ Program Studi Teknik Informatika, Fakultas Sains dan teknologi, Universitas \\ Muhammadiyah Sidoarjo
}

\begin{abstract}
Development of an application to control the activation of new indihome pairs at PT. Telkom Sidoarjo is a necessity that needs to be realized in order to support the performance of helpdesk employees in the process of activating indihome services. In developing the application, a method is needed to be able to design and build applications to meet expectations. Long polling method is one method used to get updates on bots. With the longpolling method, the server will periodically check to the bot whether there are incoming messages. If there is an incoming message, the server will execute based on the request message sent by the user. If there is no message then the server condition is idle (idle). Based on the results of planning, making and testing applications that have been carried out. It was concluded that the Indihome New Install Activation Control Application can input customer data via the SIKPRO bot, check order progress status and the Helpdesk can update order status and provide order feedback through the SIKPRO website. Bots can refuse order requests in case of double requests with the same registration number. Supervisors and Team Leaders can also recap the indihome service activation data based on daily and monthly periods.
\end{abstract}

Keywords - Install New; Indihome; Telegram; Website

\begin{abstract}
Abstrak. Pembangunan aplikasi pengawalan aktivasi pasang baru indihome pada PT.Telkom Sidoarjo merupakan suatu kebutuhan yang perlu direalisasikan demi menunjang kinerja pegawai helpdesk dalam proses aktivasi layanan indihome. Dalam pembangunan aplikasi tersebut diperlukan sebuah metode untuk dapat merancang dan membangun aplikasi agar sesuai dengan harapan. Metode Long polling merupakan salah satu metode yang digunakan untuk mendapatkan update pada bot. Dengan metode long-polling, maka server akan mengecek secara periodik ke Bot apakah ada pesan yang masuk. Jika ada pesan masuk maka server akan melakukan eksekusi berdasarkan pesan request yang dikirim pengguna. Jika tidak pesan maka kondisi server diam (idle). Berdasarkan hasil perencanaan, pembuatan dan pengujian aplikasi yang sudah dilakukan. Didapatkan kesimpulan bahwa Aplikasi Pengawalan Aktivasi Pasang Baru Indihome ini bisa melakukan input data pelanggan melalui bot SIKPRO, mengecek status progress order dan Helpdesk dapat mengupdate status order dan memberi feedback order melalui website SIKPRO. Bot dapat menolak permintaan order jika terjadi dobel permintaan dengan nomor registrasi yang sama. Supervisor dan Team Leader juga dapat merekap data aktivasi layanan indihome berdasarkan periode harian maupun bulanan.
\end{abstract}

Kata Kunci - Pasang Baru; Indihome; Telegram; Website

\section{Pendahuluan}

PT. Telkom Indonesia merupakan perusahaan yang berjalan di bidang penyedia jasa layanan komunikasi dan internet yang berada di Indonesia. Indihome ialah layanan bundling triple play yang memberikan layanan Telepon rumah, Internet dan Useetv [1]. Pada bulan November 2020 mencapai 5,909 untuk pelanggan yang berlangganan Triple Play dan mencapai 16,367 untuk pelanggan yang berlangganan Dual Play [2].Pada suatu perusahaan ataupun instansi, pasti menginginkan suatu perubahan yang dapat menunjang untuk kemajuan perusahaanya [3]. Dimana perubahan tersebut dapat membantu karyawan bekerja lebih cepat dan efisien..

Pada saat pengolahan data aktivasi pasangan baru di Telkom Witel Sidoarjo masih disimpan secara manual, artinya banyak permintaan aktivasi layanan Indihome yang tidak diproses dengan cepat oleh dikarenakan tumpukan order dan prosesnya tidak terkontrol. Aktivasi ke rumah pelanggan juga membutuhkan waktu lebih lama dari 
perkiraan waktu pengerjaan. Oleh karena itu, diperlukan Pengawalan Aktivasi Pasang Baru Indihome dengan fitur Telegram yang terhubung dengan database untuk memudahkan proses pelurusan data permintaan aktivasi pasang baru. Sehingga nantinya data permohonan aktivasi instalasi baru tidak terlewat atau tidak diproses oleh Helpdesk.

\section{Pengawalan}

Pengawalan merupakan salah satu kegiatan yang terjadi dalam interaksi antara seseorang dengan orang lain baik secara langsung maupun secara tidak langsung.Dalam KBBI mengartikan bahwasannya pengawalan adalah bentuk usaha untuk melayani kebutuhan orang.lain [4]. Pengawalan dapat dimaksudkan sebagai mengawal orderorder aktivasi layanan indihome yang dimintakan oleh teknisi. Sehingga tidak ada order yang anomaly maupun terlewat untuk aktivasi layanan.

\section{Aktivasi}

Aktivasi merupakan proses untuk pengaktivasian layanan indihome yang meliputi internet, useetv dan telephone [5].Dalam proses aktivasi diperlukan data lapangan yang nantinya digunakan untuk proses aktivasi layanan. Data tersebut berupa serial number modem, label ODP (Optical Distributin Point), nomor pendaftaran pelanggan.

\section{Pasang Baru}

Pasang baru adalah proses pengajuan dimana calon pelanggan mengajukan permohonan kepada PT Telkom untuk melakukan pasang baru layanan indihome disuatu area sesuai perminttan pelanggan [6].Dalam pengajuan pasang baru indihome tentunya ada prosedur atau sistem yang harus terpenuhi berdasarkan ketentuannya, prosedur ini berfungsi untuk memberikan kemudahan dan kepastian waktu pemasangan pasang baru indihome.

\section{Telegram}

Telegram sebagai aplikasi pesan instan mengklaim mampu menutupi beberapa kekurangan yang ada pada aplikasi lain. Sebagai aplikasi pesan singkat real-time, Telegram menawarkan akses mudah kepada pengguna karena tersedia di platform seluler dan desktop. Telegram mengklaim sebagai aplikasi pesan massal tercepat dan teraman di pasar [7]. Selain itu, Telegram juga menyediakan platform untuk pengembang yang ingin memanfaatkan API terbuka dan protokol yang disediakan oleh pengembangan bot Telegram yang didokumentasikan di situs web resmi.

\section{Bot Telegram}

Telegram Bot merupakan akun Telegram khusus yang didesain dapat merespon pesan secara otomatis, yang tidak memerlukan nomor telepon tambahan [3]. Pengguna dapat berinteraksi dengan Bot dengan mengirimkan pesan perintah (command) melalui pesan private maupun group. Bot biasanya diprogram agar bias berinteraksi seperti seseorang pada umumnya. Bot bisa dimanfaatkan mengingatkan sesuatu (reminder), bermain, broadcast, bahkan dapat mengirim perintah/ command ke perangkat lain.

Beberapa penelitian penggunaan Telegram Bot sebelumnya telah dilakukan seperti memanfaatnya Telegram untuk otomatisasi layanan dan informasi mahasiswa dalam konsep smart campus baik layanan umum, akademik maupun keuangan dengan hasil yang diberikan berupa teks atau dokumen PDF [8].

\section{Token API}

Token API adalah tanda pengenal unik atau kode unik yang digunakan untuk meminta akses kedalam suatu layanan. Layanan akan menghasilkan token API untuk aplikasi yang dimana fungsinya nanti adalah meminta layanan [9]. Kode unik didapat dari gabungan antara perangkat keras dan data alamat IP, dan waktu lain yang dihasilkan secara acak oleh server tersebut. Adanya token API nantinya digunakan untuk proses pengguna. Contoh token API terdapat pada gambar 1 .

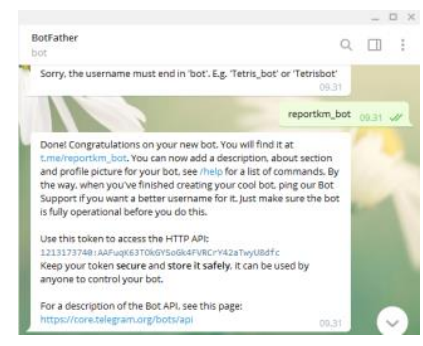

Gambar 1. Contoh Token API Telegram

\section{Long Polling}


Long polling adalah Teknik dimana Ajax request dibuat, Server menunggu data yang diminta tersedia dengan loops atau sleeps, koneksi akan terus dibuka dan setelah data tersedia dan siap akan dikirimkan ke client sehinga client mendapatkan Updatae dengan segera. Dengan metode longpolling, maka server akan mengecek secara periodik ke Bot apakah ada pesan yang masuk. Jika ada pesan masuk maka server akan melakukan eksekusi berdasarkan pesan request yang dikirimpengguna. Jika tidak pesan maka kondisi server diam (idle) [10].

\section{Webhook}

Webhook merupakan salah satu metode yang dimana saat bot menerima pesan, pesan tersbut akan diteruskan ke sebuah URL web. Web Server akan berapa pada hosting dan wajib memakai https. Sehingga bot yang berada di server bisa diakses oleh user lain. Hal ini dikarenakan API Telegram Bot yang mengijinkan developer untuk membuat sebuah bot berdasarkan 'bot' yang di inginkan. Sehingga ada Input-Proses-Output yang terjadi pada bot telegram [11].

\section{Python}

Python dikembangkan oleh Guido van Rossum pada tahun 1989 dan pertama kali diperkenalkan pada tahun 1991. Dan merupakan bahasa pemrograman tingkat tinggi. Untuk memudahkan programmer menyelesaikan tugas dengan cepat, lahirlah Python. Dalam hal efisiensi waktu baik dalam pembuatan perangkat lunak maupun pengembangan sistem, Python dirancang untuk memberikan keuntungan bagi para programmer. Program yang berdiri sendiri dan pemrograman skrip dapat dibangun dengan Python (Scripting Programming) [12].

\section{PHP}

PHP adalah bahasa yang disiapkan secara khusus untuk melakukan pengembangan maupun pembuatan website. PHP adalah salah satu tool untuk pembangunan sebuah web yang dinamis. PHP adalah singkatan dari Personal Home Page (situs pribadi) [13]..PHP sering disebut sebagar server-side embedded scriptlanguage yang berarti sintak dan perintah yang sudah kita perintahkan yang kita berikan akan seutuhnya di proses oleh server, akan tetapi disertakan pada halaman HTML [14].

\section{METODE}

\section{Pengumpulan Data}

Pada penelitian ini penulis menggunakan metode data melalui observasi, wawancara, untuk mengumpulkan data dan informasi.

1. Observasi

Melalui observasi dan catatan pada objek yang akan dianalisis, dengan menggunakan teknik pengumpulan data. Pengamatan ini dilakukan langsung di kantor pusah PT TELKOM Sidoarjo Jl Ahmad Yani No 14 Rw 04, Sidokare, Sidoarjo. Observasi dilakukan antara awal bulan November 2020 hingga akhir bulan November 2020.

2. Wawancara

Selanjutnya adalah menggunakan teknik pengumpulan data secara wawancara dengan melakukan sesi Tanya jawab bersama pihakpihak yang terlibat dalam objek penelitian yang dilakukan penulis. Wawancara dilakukan dengan beberapa pihak terkait seperti Supervisor dan Helpdesk Unit Pasang Baru di Telkom Sidoarjo. Dari wawancara tersebut ditemukan beberapa permasalahan diantaranya, sering terjadinya banyak order permintaan aktivasi pasang baru yang belum terprogress dan belum adanya pencatatan data perangkat yang terdaftar di lokasi dengan disistem.

\section{Proses Bisnis}

Proses bisnis ini bertujuan untuk menguraikan secara sistematis tentang aktivitas-aktivitas yang terjadi pada proses aktivasi layanan indihome di PT Telkom Witel Sidoarjo. Untuk mendapatkan gambaran yang lebih jelas mengenai proses bisnis, akan dijelaskan uraian dibawah ini:

1. Teknisi mendatangi team leader untuk mengambil data pelanggan yangakan diaktivasi layanan indihome.

2. Team leader memberikan data pelanggan berupa tipe order (AO: Order Pasang baru, MO: Order pindah paket, PDA: Order Pindah Alamat, CONFIG: Order aktivasi layanan ulang), data tersebut meliputi nomor registrasi(SC32232558), serial modem dilokasi pelanggan (ZTEGC6754546), Kode sub Area (SDA,TUN,SPJ), kode box odp (ODP-SDA-003) dan kode teknisi (F5SDA445).

3. Teknisi melakukan input data pelanggan ke bot yang berisikan tipe order, nomor registrasi pelanggan, serial modem dilokasi pelanggan, kode area, kode box odp dilapangan, kode teknisi.

4. Bagian Helpdesk mengecek status data pelanggan.

5. Helpdesk melakukan aktivasi layanan indihome 
6. Helpdesk memberikan feedback terkait aktivasi layanan indihome

7. Team leader membuat laporan data aktivasi layanan indihome

8. Supervisor melakukan evaluasi data aktivasi layanan indihome.

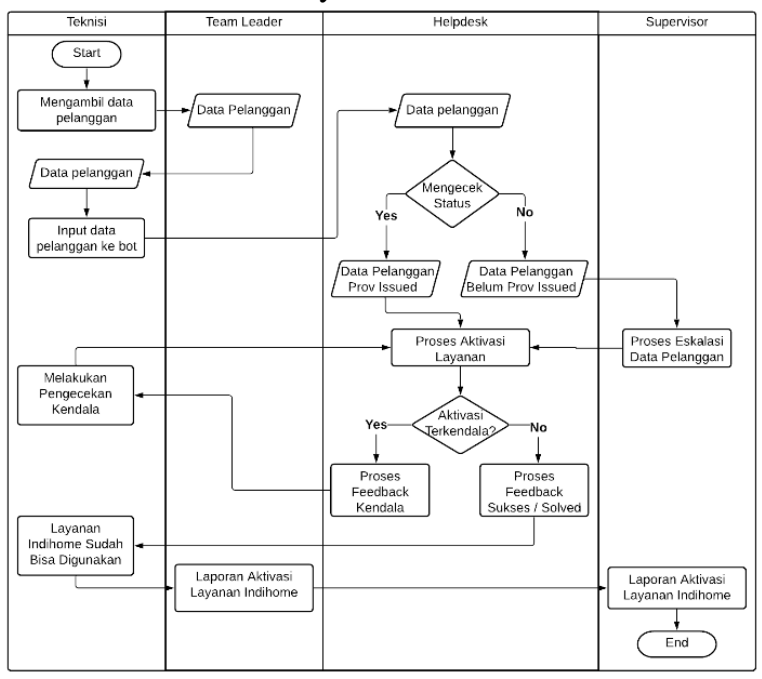

Gambar 2. Proses Bisnis Aktivasi Layanan Indihome

\section{Metode Long Polling}

Long Polling adalah salah satu metode yang digunakan untuk mendapatkan update pada bot. Long Polling merupakan teknik dimana Ajax request dibuat, Server menunggu data yang diminta tersedia dengan loops atau sleeps, koneksi akan terus dibuka dan setelah data tersedia dan siap akan dikirim ke client sehingga client mendapatkan Update dengan segera. Dengan metode long-polling, maka server akan mengecek secara periodik ke Bot apakah ada pesan yang masuk. Jika ada pesan yang masuk maka server akan melakukan eksekusi berdasarkan pesan request yang dikirim pengguna. Jika tidak ada pesan maka kondisi server idle [10]. API Telegram Bot yang mengijinkan developer untuk membuat sebuah bot berdasarkan 'bot' yang mereka inginkan. Sehingga ada Input Proses - Output yang terjadi pada bot telegram. Teknik LongPolling membutuhkan local server untuk proses bot telegram dan menggunakan PHP dengan format JSON untuk pertukaran data antar aplikasi [15] .

\section{Arsitektur Bot Telegram}

Arsitektur sistem bot telegram dapat dilihat pada Gambar 3.2 user dalam penelitian ini adalah teknisi memberikan pesan atau perintah kepada Bot Telegram melalui Aplikasi Telegram. Pesan kemudian diterima oleh Bot. server akan mengolah pesan tersebut, dan memberikan respon yang tepat kepada teknisi. Respon akan dikirim pada Aplikasi Telegram teknisi melalui server .

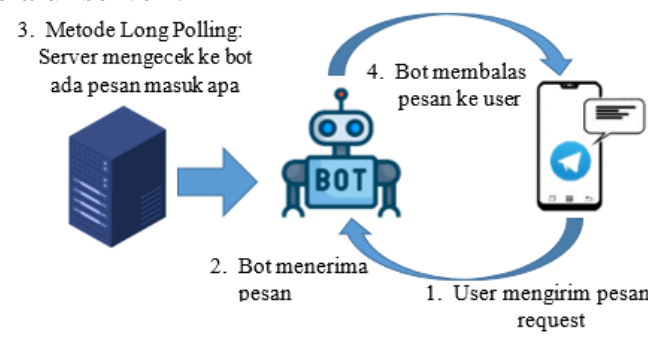

Gambar 3. Arsitektur Bot Telegram

Bot akan bisa menerima beberapa perintah yang dapat digunakan untuk penggunanya. Antara lain adalah: 
Procedia of Engineering and Life Science Vol. 2. No. 1 October 2021

Seminar Nasional \& Call Paper Fakultas Sains dan Teknologi (SENASAINS 3nd)

Universitas Muhammadiyah Sidoarjo

Table 1. Berikut Tabel Command Bot Yang Bisa Digunakan User

\begin{tabular}{|c|c|c|l|}
\hline No & Command & Output & \multicolumn{1}{|c|}{ Keterangan } \\
\hline 1 & /start & Teks & Perintah untuk memulai bot \\
\hline 2 & /reg & Teks & $\begin{array}{l}\text { perintah ini digunakan untuk input data pelanggan yang nantinya akan dilakukan } \\
\text { untuk proses aktivasi layanan. }\end{array}$ \\
\hline 3 & /cek & Teks & $\begin{array}{l}\text { perintah ini digunakan untuk mengecek progress data aktivasi layanan apakah } \\
\text { sudah diaktivasi atau belum atau bisa jadi data pelanggan tersebut terkendala. }\end{array}$ \\
\hline 4 & /help & Teks & $\begin{array}{l}\text { perintah ini digunakan untuk menampilkan fungsi perintah-perintah yang } \\
\text { digunakan dalam bot tersebut. }\end{array}$ \\
\hline
\end{tabular}

\section{Hasil dan Pembahasan}

\section{Pengujian Sistem}

Setelah melakukan perancangan dan pembuatan sistem maka tahap selanjutnya ialah melakukan pengujian pada sistem untuk memastikan apakah sudah berjalan sesuai dengan perancangan yang di inginkan. Sistem ini berguna untuk memudahkan helpdesk dalam pengolahan data permintaan aktivasi layanan indihome. Berikut adalah tampilan hasil pengujian program yang dibangun pada PT Telkom Witel Sidoarjo berbasis Website dan Bot Telegram :

Table 2. Tabel Pengujian Pada Website SIKPRO

Tabel Pengujian Pada Website SIKPRO

\begin{tabular}{|c|c|c|c|c|}
\hline No & Pengujian & Harapan & Hasil Pengamatan & Ket \\
\hline 1 & Login & $\begin{array}{l}\text { Sistem bisa melakukan perbedaan } \\
\text { level akses login }\end{array}$ & $\begin{array}{l}\text { Bisa masuk sistem sesuai level akses } \\
\text { user }\end{array}$ & $\mathrm{OK}$ \\
\hline 2 & Dashboard & $\begin{array}{l}\text { Sistem dapat menampilkan total jenis } \\
\text { order dan detail progress order }\end{array}$ & $\begin{array}{l}\text { Bisa menampilkan total jenis order } \\
\text { dan detail progress order }\end{array}$ & $\mathrm{OK}$ \\
\hline 3 & Permintaan Order & $\begin{array}{l}\text { Sistem bisa menampilkan semua data } \\
\text { order permintaan }\end{array}$ & $\begin{array}{l}\text { Bisa menampilkan data order } \\
\text { permintaan pasang baru pada tabel } \\
\text { permintaan order }\end{array}$ & $\mathrm{OK}$ \\
\hline 4 & $\begin{array}{l}\text { Pencarian Order } \\
\text { permintaan }\end{array}$ & $\begin{array}{l}\text { Sistem bisa melakukan proses } \\
\text { pencarian order permintaan pasang } \\
\text { baru }\end{array}$ & $\begin{array}{l}\text { Bisa menapilkan hasil pencarian } \\
\text { sesuai apa yang sudah dicari }\end{array}$ & $\mathrm{OK}$ \\
\hline 5 & $\begin{array}{l}\text { Input Order } \\
\text { Permintaan }\end{array}$ & $\begin{array}{l}\text { Sistem bisa melakukan proses input } \\
\text { order permintaan melalui web }\end{array}$ & $\begin{array}{l}\text { Bisa memasukkan data order } \\
\text { permintaan ke tabel permintaan order }\end{array}$ & $\mathrm{OK}$ \\
\hline 6 & $\begin{array}{l}\text { Update Progress } \\
\text { Order }\end{array}$ & $\begin{array}{l}\text { Sistem bisa melakukan proses update } \\
\text { progress status order }\end{array}$ & $\begin{array}{l}\text { Bisa update progress order dan } \\
\text { berhasil menyimpan hasilnya }\end{array}$ & $\mathrm{OK}$ \\
\hline 7 & $\begin{array}{l}\text { Feedback ke } \\
\text { telegram }\end{array}$ & $\begin{array}{l}\text { Sistem bisa mengirim hasil feedback } \\
\text { lewat telegram }\end{array}$ & Bisa kirim feedback lewat telegram & $\mathrm{OK}$ \\
\hline 8 & Hapus order & $\begin{array}{l}\text { Sistem bisa melakukan hapus data } \\
\text { order permintaan }\end{array}$ & $\begin{array}{l}\text { Bisa melakukan hapus data } \\
\text { permintaan order }\end{array}$ & $\mathrm{OK}$ \\
\hline 9 & User & $\begin{array}{l}\text { Sistem bisa menampilkan daftar user } \\
\text { yang terdaftar }\end{array}$ & $\begin{array}{l}\text { Bisa menampikan data user yang } \\
\text { sudah terdaftar pada sistem }\end{array}$ & $\mathrm{OK}$ \\
\hline 10 & Site Operation & Sistem bisa menampilkan data & Bisa menampikan data identitas site & $\mathrm{OK}$ \\
\hline
\end{tabular}


Procedia of Engineering and Life Science Vol. 2. No. 1 October 2021

Seminar Nasional \& Call Paper Fakultas Sains dan Teknologi (SENASAINS $3^{\text {nd }}$ )

Universitas Muhammadiyah Sidoarjo

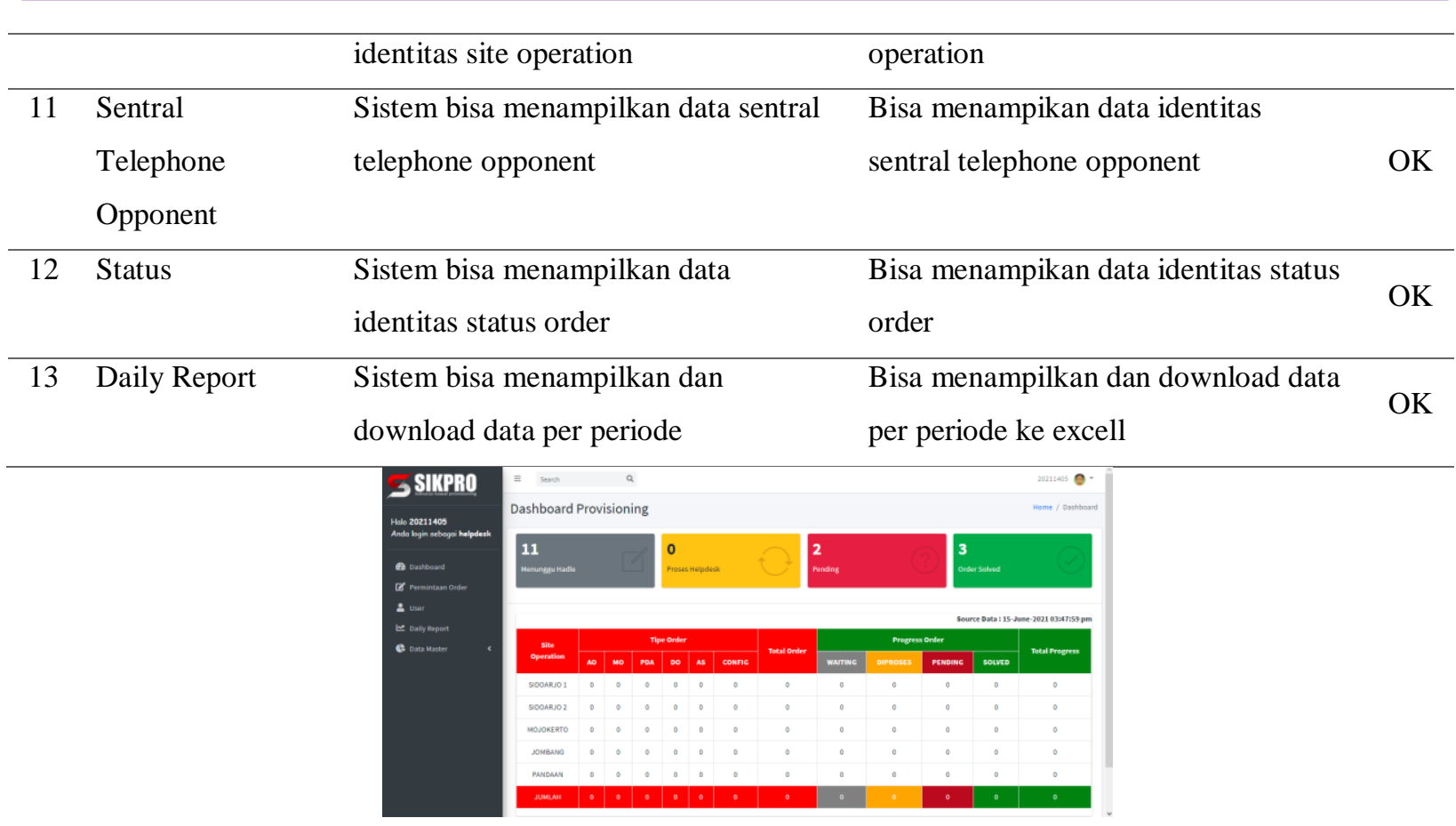

Gambar 4. Tampilan Halaman Dashboard Website

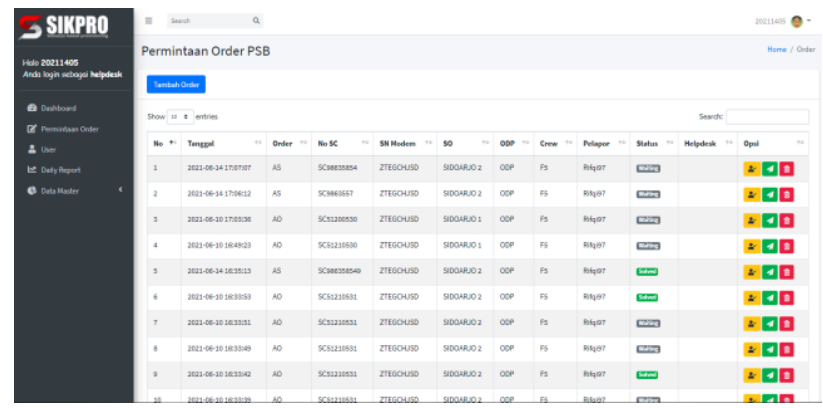

Gambar 5. Tampilan Rekap Data Permintaan Order Aktivasi Layanan Indihome

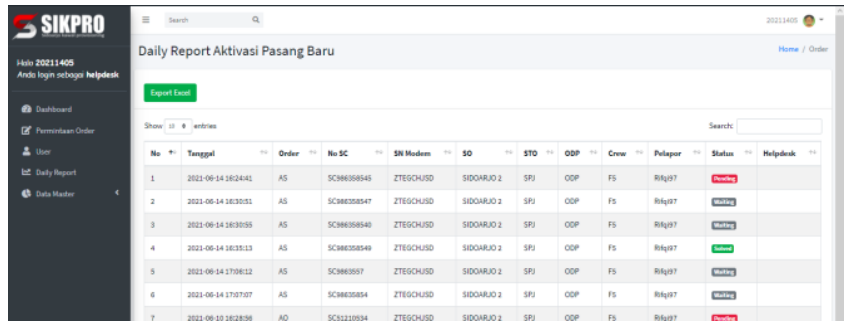

Gambar 6. Tampilan Rekap Data Aktivasi Layanan Bulanan

Tabel 3. Tabel Pengujian Bot Telegram SIKPRO

\begin{tabular}{cllcr}
\hline \multicolumn{5}{c}{ Tabel Pengujian Bot Telegram SIKPRO } \\
\hline No & Pengujian & Harapan & Hasil Pengamatan & Ket \\
\hline 1 & /start & Pengujian command start & Bot dapat membalas pesan "selamat datang" & OK \\
\hline 2 & /reg & Pengujian input data & Data permintaan disimpan dalam basis data dan & OK \\
& & permintaan PSB & bot akan membalas dengan "pesan diterima, & \\
\hline
\end{tabular}


Procedia of Engineering and Life Science Vol. 2. No. 1 October 2021

Seminar Nasional \& Call Paper Fakultas Sains dan Teknologi (SENASAINS $3^{\text {nd }}$ )

Universitas Muhammadiyah Sidoarjo

\begin{tabular}{|c|c|c|c|c|}
\hline & & & mohon ditunggu" & \\
\hline 3 & /cek & $\begin{array}{l}\text { Pengujian cek status } \\
\text { progress permintaan }\end{array}$ & $\begin{array}{l}\text { Bot dapat membalas dengan status data } \\
\text { permintaan yang sudah di update di web } \\
\text { aplikasi pengawalan }\end{array}$ & $\mathrm{OK}$ \\
\hline & /help & Pengujian comman help & $\begin{array}{l}\text { Bot dapat membalas pesan dengan } \\
\text { menampilkan command-command yang di } \\
\text { dukung di aplikasi tersebut }\end{array}$ & $\mathrm{OK}$ \\
\hline
\end{tabular}

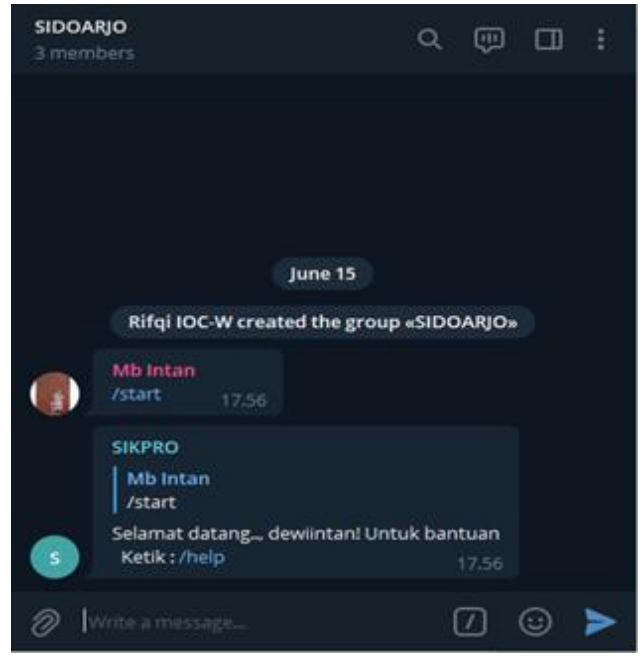

Gambar 7. Tampilan saat user input command/start

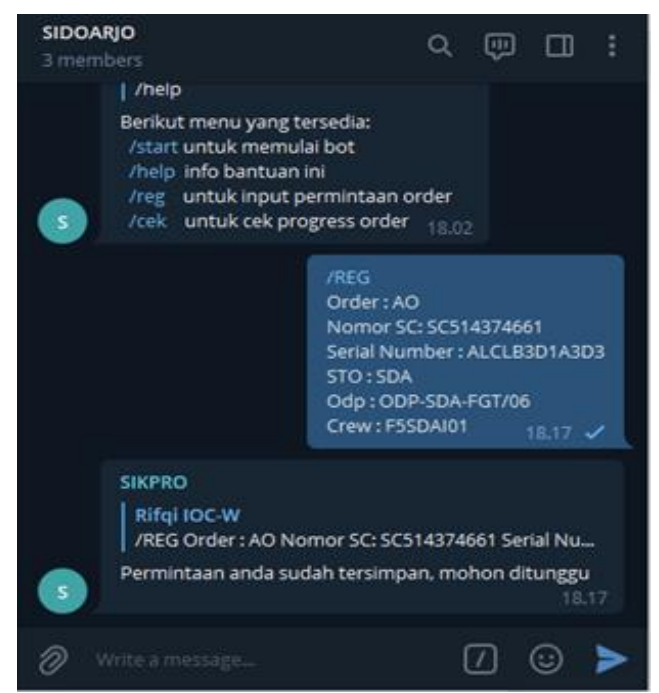

Gambar 9. Tampilan saat user input permintaa data aktivasi

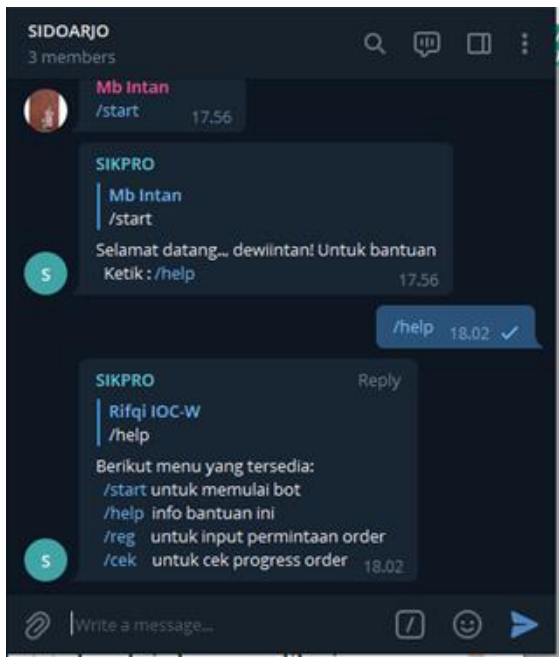

Gambar 8. Tampilan saat user input command /help

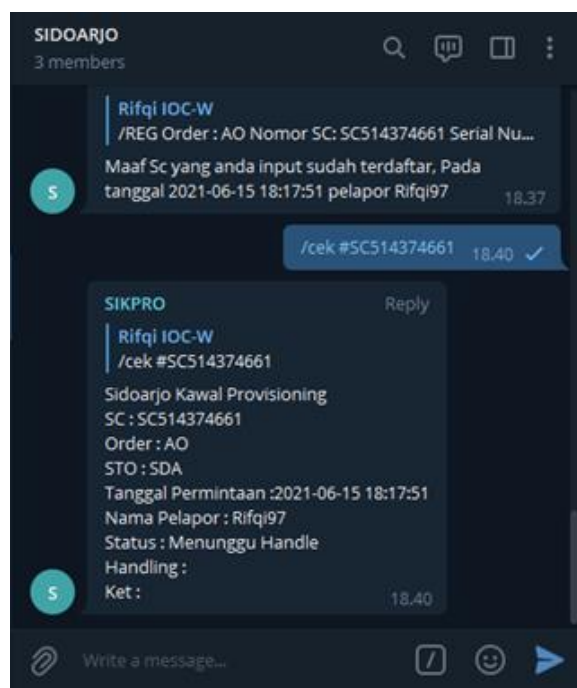

Gambar 10. Tampilan User Saat Cek Status Progress Order

\section{KESIMPULAN}

Setelah semua hasil pengujian yang telah dianalisa, dapat ditarik kesimpulan bahwa : 
1. Hasil dari pengujian akses menunjukkan bahwa Aplikasi Pengawalan Aktivasi Pasang Baru Indihome ini bisa melakukan input data pelanggan melalui bot SIKPRO. Dan dapat mengecek status order menggunakan bot tersebut.

2. Helpdesk juga dapat mengupdate status order dan memberi feedback order dari website SIKPRO.

3. Bot SIKPRO dapat menolak permintaan order jika terjadi dobel permintaan dengan nomor registrasi yang sama

4. Supervisor dan Team Leader dapat merekap data aktivasi layanan indihome berdasarkan periode harian maupun bulanan.

\section{UCAPAN TERIMA KASIH}

Untuk itu pada kesempatan kali ini saya ingin mengucapkan terima kasih kepada pihak-pihak yang telah membatu saya secara langsung maupun tidak langsung dalam penulisan laporan Skripsi ini. Saya ucapkan terimakasih secara khusus kepada :

1. Dr. Hidayatullah, M.Si. Selaku Rektor Universitas Muhammadiyah Sidoarjo yang telah menyediakan fasilitas dalam perkuliahan

2. Dr. Hindarto, S.Kom., M.T. Selaku Dekan Fakultas Sains dan Teknologi yang telah mengfasilitasi se lama perkuliahan.

3. Ir. Sumarno., MM. Selaku Ketua program studi Informatika Fakultas Sains dan Teknologi yang telah menyediakan fasilitas dalam perkuliahan.

4. Arif Senja Fitrani S.Kom., M.Kom. Selaku Dosen Pembimbing yang sudah memberikan bimbingan dan bantuan dalam menyelesaikan skripsi ini.

5. Bapak Ibu Dosen Informatika yang memberikan arahan selama masa studi

6. Kedua Orang Tua kami yang selalu memberi support dan do "a terbaik kepada kami.

7. Dan teman-teman yang sudah membantu dalam penyusunan jurnal ini.

Akhir kata, semoga laporan ini dapat menjadi referensi untuk menambah wawasan para pembaca serta dapat memberikan manfaat.

\section{REFERENSI}

[1] Indihome, "Syarat dan Ketentuan," Indihome.co.id, 4 Desember 2020. [Online]. Available: https://indihome.co.id/syarat-ketentuan. [Diakses 15 Januari 2021].

[2] M. H. E. Luthfia Zein Pettarani, "Pengaruh Kualitas Layanan Terhadap Kepuasan Pelanggan di Kantor Telkom IndiHome Makassar,” Jurnal Ilmu Ekonomi, vol. II, no. 2, pp. 3-4, 2019.

[3] A. S. Raga Nufusula, "Rancang Bangun Chat Bot Pada Server Pulsa Mengunakan Telegram Bot API," Journal of Information System, vol. I, no. 1, pp. 1-2, 2018.

[4] F. Widarini, "Hubungan pelayanan prima (service excellence) dengan loyalitas nasabah Bank Mandiri Cabang Genteng Banyuwangi," Thesis (Undergraduate), vol. 1, no. 1, pp. 11-13, 2013.

[5] R. H. M. Radiant Victor Imbar, "Analisis Pemodelan Sistem Informasi Telkom Speedy Menggunakan Zachman Framework," Jurnal Sistem Informasi, vol. III, no. 2, pp. 161-163, 2008.

[6] M.W.Lucia Amelia, "PROSEDURPELAYANANPASANGBARULISTRIKUNTUKPERUMAHANPADAPT PLN(PERSERO)AREASEMARANG,”Thesis(Undergraduate), vol.I,no.1,pp.25-27,2017.

[7] A. Z. A. E. M. T. Hariyanto Soeroso, "Penggunaan Bot Telegram Sebagai Announcement Systempada Intansi Pendidikan,"vol.1509,p.45-48,2017.

[8] G. Sastrawangsa, "Pemanfaatan Telegram Bot Untuk Automatisasi Layanan Dan Informasi Mahasiswa Dalam KonsepSmartCampus," dalam KonferensiNasional Sistem \&Informatika, Bali, 2017.

[9] “NOTIFIKASIJARINGANPADAROUTERMIKROTIKBERBASISBOTTELEGRAM,”Thesis(Skripsi), vol.I, no. 1,pp. 19-22,2019.

[10] A. Z. A. N. E. M. Hariyanto Soeroso, "Penggunaan Bot Telegram Sebagai Announcement System pada Intansi Pendidikan,"dalamSeminarMASTER,Madiun, 2017.

[11] P. A. Moh. Anshori Aris Widya, "Pengembangan Telegram Bot Engine Menggunakan Metode Webhook Dalam RangkaPeningkatan WaktuLayananE-Government,"JurnalSainsdanTeknologi, vol.12, no.2,pp.14-15,2020.

[12] M. K. S. F. H. Siti AlifatulQutsiah, “Aplikasi Pembelajaran Matematika Dasar Bangun Datar Menggunakan Python 
Procedia of Engineering and Life Science Vol. 2. No. 1 October 2021

Seminar Nasional \& Call Paper Fakultas Sains dan Teknologi (SENASAINS 3nd)

Universitas Muhammadiyah Sidoarjo

PadaPerangkatBergerak,”JurnalTeknologiInfromasidanKomunikasi, vol.XI,no.3,pp. 14-15, 2016.

[13] N. Nuraeni, "Perancangan Sistem Informasi Akademik Berbasis Website Pada Madrasah Tsanawiyah Yayasan FisabillilahBekasi,"JurnalSwabumi, vol.6,no.2,pp.104-109,2018.

[14] Y. N. R. ElisaUsada, "Rancang Bangun Sistem Informasijadwal Perkuliahan Berbasis Jquery Mobiledengan MenggunakanPhpDanMysql,”Jurnal Infotel, vol.4, no.2,pp.41-44,2012.

[15] A.S.FakhriyanNurRofiq, "ImplementasiRESTfulWebServiceuntukSistemPenghitunganSuaraSecaraCepatpada Pilkada,"EksploraInformatika, vol.6, no.2,pp.161-164,2017.

[16] G. Sastrawangsa, "Pemanfaatan Telegram Bot Untuk Automatisasi Layanan Dan Informasi Mahasiswa Dalam KonsepSmartCampus,”dalam KonferensiNasionalSistem \&Informatika,Bali, 2017. 